\title{
Ethnomathematics: Traveling Trade on The Musi River
}

\author{
Malalina Malalina ${ }^{1, *}$ Ratu I. I. Putri ${ }^{2}$ Zulkardi Zulkardi ${ }^{2}$, Yusuf Hartono ${ }^{2}$ \\ ${ }^{1}$ Department of Teaching Training and Education, Universitas Tamansiswa, Palembang, Indonesia \\ ${ }^{2}$ Department of Teaching Training and Education, Universitas Sriwijaya, Inderalaya, Indonesia \\ *Corresponding author. Email: ratuilma@unsri.ac.id
}

\begin{abstract}
The culture around students can be used to understand mathematical concepts even though there is not much linking the culture in students in the learning process. This study aims to discover the mathematical concepts in traveling trading activities on the Musi River. The research subject is a traveling merchant who trades Palembang local food using traditional boats on the Musi River. The research used is qualitative with an ethnographic approach. This study's data collection techniques are literature study, observation, interviews, and documentation. This research concludes that traveling trading on the Musi River can indirectly introduce some mathematical concepts, such as solid figure (sphere, cube), plane figure (rectangle), comparisons, social arithmetic, and system of linear equations. This research has implications for students to learn to understand mathematical concepts through the cultural values of traveling around the Musi River.
\end{abstract}

Keywords: Traveling trade, Ethnomathematics, Mathematical concepts, Musi river.

\section{INTRODUCTION}

Culture is rarely associated with learning in the modern era, such as mathematics [1]. According to Arisetyawan [2], the culture that exists in the environment of students has not been widely associated with the learning process. This culture can be seen in the mathematics learning that is learned at school is different from students' daily lives [3], [4]. So far, educators have not taken advantage of the student's environmental culture as a starting point for learning mathematics [5], [6]. The culture that exists in the environment of students has not been widely associated with the learning process.

Indonesia has many cultures that can be used to understand mathematical concepts. Moreover, Indonesia is an archipelagic country consisting of large and small islands, so that it has diversity related to cultural activities. Culture is an asset and an alternative in learning mathematics [7]. The culture around students can present abstract mathematical concepts [8]. Thus the cultural activities that exist can be utilized in learning mathematics. The cultural activities used to learn mathematics are water areas in the Musi River, Palembang.
Cultural activities that exist in daily economic activities are related to the river as a trade route, so that the river is used as the main movement of the community's economy in carrying out trading activities. River by Utomo [9]defines as a connecting line in community activities. Therefore, the river is used as a place for community life activities [10]. Not only that, rivers can grow the economy [11].

But along with the times said by Asnan [12], the position of the river in the activities of modern life is almost ignored. In addition, the use of river transportation is no longer a priority with the development of land transportation [13], [14]. Likewise with the Musi River is directly related to community activities in running the economy. In this study, we will focus on traveling traders using traditional boats as a medium of trade transportation on the Musi River.

There are trading activities in the waters of the Musi River [15]. Merchants on the Musi River in trading use boats as a means of transportation [16]. So that the Musi River as the main movement in trading activities, even made the river an important route. According to Farida et al [17] Musi River is a path of economic activity by the community. Meanwhile, 
Zahra [14] stated that the Musi River had become the main route for trade activities. This causes the Musi River to become the lifeblood of the community [18]. Thus, the Musi River has functioned as a path of economic activity in daily life activities; even the Musi River has an important position in people's life activities for the trading economy.

The above problems have attracted the attention of researchers to preserve the local food trade in Palembang using traditional boats (boat ketek) on the Musi River, which can be used as a starting point in learning mathematics. The local food trade in Palembang using a ketek boat on the Musi River indirectly contains mathematical concepts. According to Malalina et al. [19], community activities in the Musi River contain cultural elements in mathematical concepts. Putri [20] explains that many Indonesian cultures can help students enjoy and understand mathematical concepts.

According to Suripah et al. [21], mathematical concepts related to community activities. So that from community activities produce a culture that contributes to formal mathematics learning in schools. While D'Ambroisio [22] mathematical concepts can be identified from the activities of people's lives to give birth to culture, the identification results can be used as a source of learning. In addition, culture can be developed as an aspect of mathematics learning innovation [23]. Malalina et al. [24] Mathematics learning can be integrated with everyday life. So that cultural identification is in line with mathematical concepts in the 2013 curriculum, even culture can be linked to students' environment, such as in the aquatic environment. This is in line with Putri [25] stated that the 2013 curriculum learning begins by using a cultural context close to the students.

Learning mathematics can be associated with cultural activities known as ethnomathematics. Ethnomathematics can be used in learning through cultural context problems [21]. In addition, culture can be used as a context in learning mathematics in schools [3]. Ethnomathematics is part of learning innovation to train critical thinking, understanding concepts, and constructing mathematical concepts [26]. The same thing was stated by Arisetyawan [27]; ethnomathematics analyzes and explores mathematical concepts in culture. In addition, ethnomathematics can be used as a process and method of learning mathematics [28]. Thus ethnomathematics is learning mathematics associated with cultural concepts. This is done by analyzing and identifying the existing culture to find mathematical concepts. Based on the problems above, this study aims to determine the mathematical concepts in traveling trading activities on the Musi River. This research aims to identify the mathematical concepts that exist in the traveling trade in the Musi River that can be related to mathematics learning materials. This research has implications for students to learn to understand mathematical concepts through the cultural values of traveling around the Musi River.

\section{METHODS}

The research used is qualitative with an ethnographic approach. According to Creswell [29], [30], qualitative research explores many individuals or social groups using an ethnographic approach. Data collection in ethnography is done by observing, interviewing, and collecting data used in research results. The ethnographic approach used in this study aims to identify and analyze in-depth trading activities on the Musi River using traditional boats. In addition, researchers used literature studies to help identify data from findings in the field.

The research subject is a traveling merchant who trades Palembang local food using traditional boats on the Musi River. This study's data collection techniques are literature study, observation, interviews, and documentation. This research used three stages proposed by Miles \& Huberman to analyze the data [31], namely data reduction, data display, and conclusion drawing/verification. This research was conducted from September 2020 January 2021.

\section{RESULTS AND DISCUSSION}

The results of this study describe the findings from data collection in the field according to the problem from the beginning. These findings were obtained based on observations and interviews with direct informants, namely itinerant traders in the Musi River. Trading activities on the Musi River are carried out around the Musi River. It is carried out in the afternoon until the afternoon with the route of the upstream area of the Musi River, namely from 2 Ulu Village to Gandus. Traders use boats to get around the Musi River, offering their wares. This boat has been designed according to its function and needs making it easier to get around and trade on the Musi River.

The research results in traveling traders in the Musi River are the only ones that can survive to this day in the development of the times. This can be seen when traveling by boat to trade their wares. Trade activities are carried out by walking around the banks of the Musi River to meet consumers. The traveling vendors 
sell local food, namely model, martabak cuka. As for the material traded, the main ingredient is fish. This fish comes from the Musi River.

The traveling trade in the Musi River that he does daily indirectly contains mathematical concepts. To find out the mathematical concepts in traveling trade in the Musi River flow. The researcher used an observation and interview approach, as shown in Figure 1.

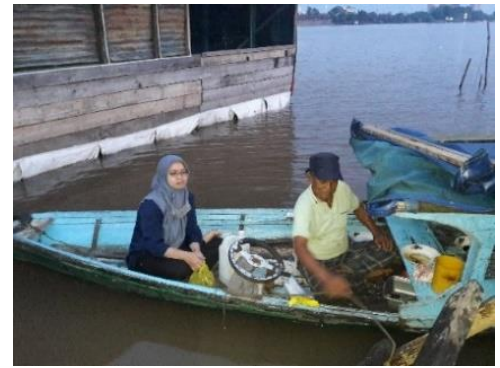

Figure 1 Merchant and researcher (Documentation of 2020).

Figure 1 above is a traveling trading activity on the Musi River. It can be seen that researchers directly participate in traveling trading activities on the Musi River. This is done to observe the activities carried out directly. In addition, researchers also conducted interviews while traveling in the Musi River.

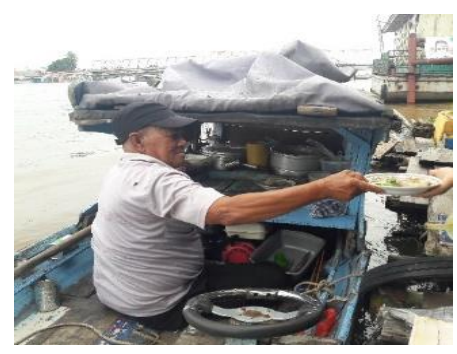

Figure 2 Merchant are delivering food to consumers (Documentation of 2020).

Figure 2 above shows a merchant pulling a boat to the edge of the Musi River to meet consumers. Seen the activities carried out between traveling traders and consumers on the Musi River's outskirts. Merchants are providing traded food to consumers.

\subsection{Food Menu}

Materials traded around by boat on the Musi River include models and martabak cuka. As for this type of food and transactions carried out indirectly contain mathematical concepts.

\subsubsection{Model}

Model is a local food from the people of Palembang. This food is served with a sauce that has been seasoned. The material for this model is made from a mixture of mashed fish as the main ingredient, wheat flour, sugar, salt, and tofu as the filling. The model can be called pempek gravy [32]. Figure 3 below is an image of the model serving form presented to consumers.

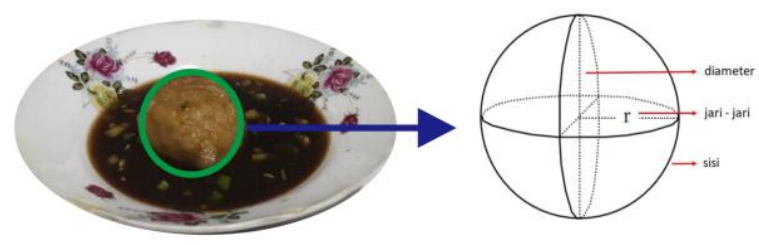

Figure 3 Model food shape (Documentation of 2020).

The picture above describes the form of food traded by traveling vendors on the Musi River. If the identified model indirectly applies the mathematical concept, the sphere is included with the mathematical concept of a solid figure.

\subsubsection{Martabak Cuka}

Martabak is one of the foods traded by traveling traders or also called by local people, namely martabak cuka. It is called martabak cuka because when serving, it comes with a sauce called cuka. Cuka is a gravy made using spices. This martabak cuka ingredient is made from various mixtures such as wheat flour, potatoes, carrots, salt, and cuka as the sauce.

Martabak comes from India, which spread through trade to Southeast Asia. As for Martabak cuka, it is adapted from Indian cuisine adapted to the acculturation of Palembang culture, namely by using a sauce called cuka [32]. The appearance of martabak cuka is shown in the following Fig. 4

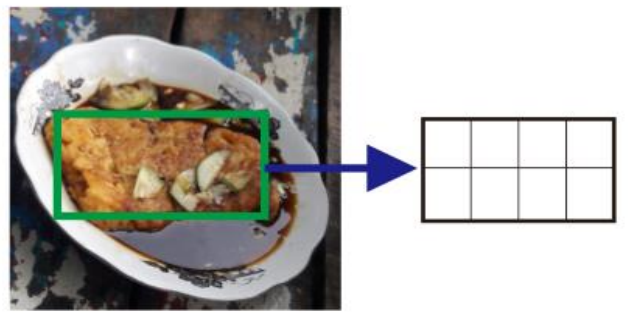

Figure 4 The appearance martabak cuka (Documentation of 2020). 
Figure 4 above describes the form of food traded around the Musi River. Food is indirectly related to mathematical concepts. The mathematical concept is a plane figure that is a rectangle. In addition, if the martabak cuka is cut into pieces, the mathematical concept is a cube.

\subsection{Payment System}

The payment system used by traveling traders uses traditional boats on the Musi River, namely the barter system and cash.

The exchange system is used if consumers do not have cash, so traders and consumers agree to exchange. In this exchange, it is usually done with consumers on Jukung boats (large boats) that lean on the banks of the Musi River. This Jukung boat carries rice from the hinterland around Palembang.

Exchanges made with consumers using rice are carried out because rice is used to transport Jukung boats. In addition, rice is the staple food of the general public, so traders can easily resell or consume the food themselves. The comparison of exchanges carried out is as shown in table 1 below:

Table 1. Exchange Comparison

\begin{tabular}{|l|l|}
\hline \multicolumn{2}{|c|}{ Exchange Comparison } \\
\hline One portion model & $1 \mathrm{~kg}$ \\
\hline One portion of martabak cuka & $1 \mathrm{~kg}$ \\
\hline
\end{tabular}

Documentation (2020)

Table 1 above compares the exchanges made between traders and consumers. Milk can be measured as one kilogram $(\mathrm{kg})$ of rice in exchange for a model or martabak cuka. The ratio of $1 \mathrm{~kg}$ of rice is equal to 4 cans of milk. In transactions carried out indirectly apply mathematical concepts, namely comparisons or systems of linear equations.

Meanwhile, the payment system in traveling trading, if using a cash transaction system, will consider the benefits obtained. The profit obtained must be calculated based on the production costs incurred to trade the food. Table 2 below is the production and selling costs used by traveling traders. This data is obtained from the results of interviews. The results of interviews with traders are as follows:

Researcher : Since when did you trade around the Musi River

Merchant : 1993

Researcher : What are traded goods?

Merchant : Model and Martabak cuka

Researcher : Do you make your merchandise?
Merchant : I took the cuka model and martabak from the maker for one portion of 3000 rupiahs and sold it again for 5000 rupiahs for one serving

The production costs and selling prices of traveling trade in the Musi River.

Table 2. Production Cost And Selling Price

\begin{tabular}{|l|c|c|c|}
\hline Snack Type & $\begin{array}{c}\text { Production } \\
\text { cost }\end{array}$ & $\begin{array}{c}\text { Selling } \\
\text { price }\end{array}$ & $\begin{array}{c}\text { Price } \\
\text { gap }\end{array}$ \\
\hline $\begin{array}{l}\text { Model } \\
\text { cuka }\end{array}$ & 3000 & 5000 & 2000 \\
\hline
\end{tabular}

Documentation (2020)

In table 2 above, the ingredients are traded around the Musi River in portion units. The production costs, selling prices, and price differences can be seen in this case. This price difference is the profit traders get every day for one portion. Profits and losses in trading are included in the mathematical concept of social arithmetic.

From the findings of data from the field, it is concluded that there is a relationship between traveling merchants in the Musi River indirectly applying mathematical concepts. The results of this analysis can be used to learn mathematical concepts that exist in students' daily environment, such as in the aquatic environment. The mathematical concepts can be seen in Table 3 below.

Table 3. Mathematical Concepts in Traveling Trading on the Musi River

\begin{tabular}{|c|c|}
\hline Type & Math Concepts \\
\hline Model & Solid Figure (Sphere) \\
\hline Martabak Cuka & $\begin{array}{c}\text { Plane Figure (rectangle), } \\
\text { Solid Figure (cube) }\end{array}$ \\
\hline $\begin{array}{c}\text { Payment System } \\
\text { (barter) }\end{array}$ & $\begin{array}{c}\text { Comparison, System of } \\
\text { Linear Equations }\end{array}$ \\
\hline Production System & Social Arithmetic \\
\hline
\end{tabular}

Table 3 above describes the analysis of data findings from the field. The findings are indirectly related to mathematical concepts. So the results of this study are in line with Suripah et al. [21] Some concepts of Riau Malay food can be used to introduce and understand geometric concepts. The mathematical elements found in market snacks in the Special Region of Yogyakarta are plane figures, solid figures, and linear equations of 2 and 3 variables [33]. 
This research aims to identify the mathematical concepts that exist in the traveling trade in the Musi River that can be related to mathematics learning materials. This research has implications for students to learn to understand mathematical concepts through the cultural values of traveling around the Musi River. The results of the identification of traveling trading research in the Musi River will be made as material in learning mathematics in teaching materials.

\section{CONCLUSION}

Based on the research that has been carried out on traveling trading on the Musi River, it can be concluded that traveling trading on the Musi River can indirectly be used as a way to introduce some mathematical concepts, such as solid figure (sphere, cube), plane figure (rectangle), comparison, social arithmetic, and system of linear equations. Based on the research results that have been done, the researchers suggest applying mathematical concepts to the traveling trade in the Musi River to be applied in the learning process. This is done so that students can easily understand mathematical concepts in the student's environment, such as the aquatic environment.

\section{AUTHORS' CONTRIBUTIONS}

Author 1 has contributed to making conceptual or ideas, research goals and objectives, conducting research and observation processes, writing drafts of scientific papers. Author 2 provides validation, input, and guidance until published. Authors 3 and 4 provided input, guiding until this article was published.

\section{ACKNOWLEDGMENTS}

The researchers would like to thank Tamansiswa University of Palembang, which has assisted in the publication of this article.

\section{REFERENCES}

[1] R. I. I. Putri, Pendisainan Hypotetical Learning Trajectory (HLT) Cerita Malin Kundang pada Pembelajaran Matematika, in: Seminar Nasional Matematika dan Pendidikan Matematika dengan Tema Kontribusi Pendidikan Matematika dan Matematika dalam Membangun Karakter Guru dan Siswa, 2012, pp. 1-9. URL: https://eprints.uny.ac.id/10080/1/P\%20$\% 2076$.pdf.
[2] A. Arisetyawan, D. Suryadi, T. Herman, and C. Rahmat, "Study of Ethnomathematics : A lesson from the Baduy Culture," International Journal of Education and Research 2 (10) (2014) 681-688. URL:

http://citeseerx.ist.psu.edu/viewdoc/download?d oi=10.1.1.1046.6613\&rep=rep1\&type=pdf.

[3] R. C. I. Prahmana and U. D’Ambrosio, "Learning Geometry and Values from Patterns: Ethnomathematics on the Batik Patterns of Yogyakarta, Indonesia", Journal on Mathematics Education 11(3) (2020) 439-456. DOI: http://doi.org/10.22342/jme.11.3.12949.439456.

[4] H. Pathuddin, Kamariah, and M. I. Nawawi, "Buginese Ethnomathematics: Barongko Cake Explorations as Mathematics Learning Resources", Journal on Mathematics Education 12(2) (2021) 295-312. DOI: https://doi.org/10.22342/jme.12.2.12695.295312.

[5] R. C. I. Prahmana, W. Yunianto, M. Rosa, and D. C. Orey, "Ethnomathematics: Pranatamangsa System and The Birth-Death Ceremonial in Yogyakarta", Journal on Mathematics Education 12(1) (2021) 93-112. DOI: 10.22342/jme.12.1.11745.93-112.

[6] A. S. Abdullah, "Ethnomathematics in Perspective Sundanese Culture", Journal on Mathematics Education. 8(1) (2016) 1-16. DOI: 10.22342/jme.8.1.3877.1-15.

[7] Turmudi, Kajian Etnomatematika: Belajar Matematika dengan Melibatkan Unsur Budaya, in Prosiding Seminar Nasional Etnomatnesia, 2017, pp. 38-53. URL: https://jurnal.ustjogja.ac.id/index.php/etnomatne sia/article/view/2292.

[8] R. Fachrur, W. Rika, and N. P. Rahayu, Ethnomathematics BT - Proceedings of the 1st International Conference on Mathematics and Mathematics Education (ICMMEd 2020), in Prosiding Konferensi Internasional 1 tentang Pendidikan Matematika dan Matematika (ICMMEd 2020), 2021, pp. 266-275. DOI: https://doi.org/10.2991/assehr.k.210508.074.

[9] B. B. Utomo, Kemaritiman Nusantara, Yayasan Pustaka Obor Indonesia, 2017.

[10] B. Subiyakto, Sungai dan Kehidupan Masyarakat Banjar: Penguatan Lokalitas dalam Wacana 
Pendidikan IPS yang Responsif, Pidato Pengukuhan Guru Besar, Universitas Lambung Mangkurat, Banjarmasin, 2020.

[11] A. Sastika and A. Yasir, "Karakteristik Permukiman di Tepian Sungai," Jurnal Koridor 8(2) (2017) 83-88. DOI: 10.32734/koridor.v8i2.1332.

[12] G. Asnan, Sungai dan Sejarah Sumatra, Ombak, 2016.

[13] B. Wicaksono, A. Siswanto, S. Kusdiwanggo, and W. F. F. Anwar, "Perubahan Orientasi Permukiman Tepi Sungai sebagai Pengaruh Eksistensi Sungai Musi Palembang," Jurnal Lingkungan Binaan Indonesia 8(2) (2019) 86-94. DOI: $10.32315 /$ jlbi.8.2.86.

[14] A. Zahra, Menelusuri Makna Ruang Publik pada Dermaga di Sungai Musi Palembang, in Prosiding Temu Ilmiah Ikatan Peneliti Lingkungan Binaan Indonesia, 2016, pp. 65-70.

[15] S. M. Siregar, "Persebaran Situs-Situs HinduBuddha dan Jalur Perdagangan di Daerah Sumatera Selatan (Indikasi Jejak-Jejak Perdagangan di Daerah Aliran Sungai Musi)," Kindai Etam Jurnal Penelitian Arkeolog 2(1) (2018) 1-10. DOI: 10.24832/ke.v2i1.5.

[16] Melisa, “Ampera dan Perubahan Orientasi Ruang Perdagangan Kota Palembang 1920an-1970an," Lembaran Sejarah 9(1) (2012) 51-68. DOI: https://doi.org/10.22146/lembaransejarah. 23768 .

[17] I. Farida, E. Rochmiatun, and N. U. Kalsum, "Peran Sungai Musi dalam Perkembangan Peradaban Islam di Palembang: Dari Masa Kesultanan sampai Hindia-Belanda," JUSPI (Jurnal Sejarah Peradaban Islam) 3(1) (2019) 5057. DOI: 10.30829/juspi.v3i1.4079.

[18] D. I. M. Santun, Venesia dari Timur : Memaknai Produksi dan Reproduksi Simbolik Kota Palembang dari Kolonial Sampai Pasca Kolonial, Ombak, 2010.

[19] M. Malalina, R. I. I. Putri, Z. Zulkardi, and Y. Hartono, "Ethnomathematics of fish catching exploration in Musi River," Journal of Physics Conference Series 1663(1) (2020) 1-6. DOI: 10.1088/1742-6596/1663/1/012007.

[20] R. I. I. Putri, "Design Research: Eksplorasi Budaya Indonesia dalam Pembelajaran Matematika," 2015.
[21] Suripah, Marsigit, and Rusli, "Etnomatematika: Eksplorasi Konsep-Konsep Matematika Pada Makanan Khas Melayu Riau," Math Didactic: Jurnal Pendidikan Matematika 7(1) (2021) 2838.

URL:

http://repository.unej.ac.id/handle/123456789/10 4850.

[22] U. D’Ambrosio, Ethnomathematics. Link Between Traditions and Modernity, Sense, 2001.

[23] Marsigit, Pengembangan Pembelajaran Matematika Berbasis Etnomatematika, in Prosiding Seminar Nasional Matematika dan Pendidikan Matematika "Etnomatematika, Matematika dalam Perspektif Sosial dan Budaya," 2016, pp. 1-38.

[24] M. Malalina, R. I. I. Putri, Z. Zulkardi, and Y. Hartono, "Ethnomatematics: Treasure Search Activity in the Musi River," Numerical: Jurnal Matematika dan Pendidikan Matematika 4(1) (2020) 31-40. DOI: 10.25217/numerical.v4i1.870.

[25] R. I. I. Putri, Soal HOTs dalam Jumping Task, in Prosiding Seminar Nasional Matematika dan Pendidikan Matematika Hot Skill in Mathematics Education, 2018, pp. 9-18.

[26] Marsigit, R. Condromukti, D. S. Setiana, and S. Hardiarti, "Pengembangan Pembelajaran Matematika Berbasis Etnomatematika," in Prosiding Seminar Nasional Pendidikan Matematika Etnomatnesia, 2018, pp. 20-38. URL:https://jurnal.ustjogja.ac.id/index.php/etno matnesia/article/view/2291.

[27] A. Arisetyawan, "Pentingnya Pembelajaran Etnomatematika dalam Meningkatkan Kemampuan Kognitif Siswa Dan Bagaimana Mendisain Bahan Ajar Berbasis Kearifan Lokal," Jurnal Basicedu 3(2) (2019) 621-626. DOI: 10.31004/basicedu.v3i2.47.

[28] L. Shirley, Using ethnomathematics to find multicultural mathematical connections, Connecting mathematics across curriculum, 34, 1995.

[29] J. W. Creswell, Research Design Wualitative, Quantitative and Mixed Methods Approaches, Sage, 2014.

[30] J. W. Creswell, Riset Pendidikan Perencanaan, Pelaksanaan dan Evaluasi Riset Kualitatif dan Kuantitatif, Pustaka Pelajar, 2015. 
[31] M. B. Miles and A. M. Huberman, Qualitative Data Analysis: a Methods source, Sage, 1994.

[32] Food.detik.com, "Martabak Telur Diadaptasi dari Kuliner India, Ini Catatan Sejarahnya," food.detik.com, 2021, URL: https://food.detik.com/info-kuliner/d5650253/martabak-telur-diadaptasi-dari-kulinerindia-ini-catatan-sejarahnya.

[33] N. T. Huda, "Etnomatematika Pada Bentuk Jajanan Pasar di Daerah Istimewa Yogyakarta," JNPM (Jurnal Nasional Pendidikan Matematika 2(2) (2018) 217-232. DOI: http://dx.doi.org/10.33603/jnpm.v2i2.870. 